\title{
Editorial
}

\section{Can governments innovate?}

The $21^{\text {st }}$ century is revealing, perhaps more sharply than ever before, the urgent need for innovation both in the development of new products \& services and, perhaps synchronously, in the introduction of new channels through which innovations can be both stimulated and delivered. To infer from the "long wave theory' of the Russian economist Nikolai Kondratiev, we seem to be living a wave of innovation sourced from the tentacular spreading of ICTs into everyday and workaday life, intensely stimulated by new forms of information and their communication. Schumpeter's 'gales of creative destruction' has never been a more apposite metaphor for helping to describe and understand the pace of change in the so-called developed world than it is today. But how does Government react to these stormy times?

Innovation is a subject that demands deep consideration in scientific journals such as this, as well as in the popular media. Its attraction, in part at least, lies in it seemingly being able to set up the possibility of an emergent golden age or, if not that heady prospect, at least an escape from an age seemingly tarnished indelibly by unsustainable economic and political behaviours. Innovation can create the things that people really want and deliver those same things in ways that people find most convenient. And innovation can also mobilise people, experts and lay people, both in the design of new products and services and in so-doing develop new forms of 'productive democracy'. As Don Tapscott and Anthony D Williams show in their recent book ${ }^{1}$, 'wikinomics', in a myriad of forms, is enabling unprecedented levels of collaboration to produce innovations in every field of human activity. And, echoing Sunstein's 'Infotopia', ${ }^{2}$ these authors demonstrate the 'knowledge power' and 'innovative potency' resident within collaborating groups.

But all that I have written above appears largely beyond the scope of Governments at present. Governments are institutionalised, working from the familiar and uncomfortable with the new. Can Government do more than set conditions supportive of business innovation and actually pursue and implement innovations itself? Of course, the simple answer to this question has to be 'yes', even though studies of government in action, such as those captured here by Victor Bekkers in the innovation section of this edition, suggest otherwise. How can Governments unfreeze their institutionalised, isomorphic ways of doing? Can Governments engage with web 2.0 and 'wikinomics' thinking and engage and innovate in new ways with their citizens? As Victor Bekkers propounds "The ultimate test of successful modernization is the ability of government to act as a legitimate political organization. This is the essence of public innovation."

Innovation is a massive topic for those concerned with government and democracy in this information age, one to which this journal will undoubtedly return at some future point. The interplay between information, innovation and risk may prove significant for future contributors to the literature on this

\footnotetext{
${ }^{1}$ Don Tapscott and Anthony D Williams, Wikinomics: How Mass Collaboration Changes Everything, Published by Portfolio (US), Atlantic (UK).

${ }^{2}$ Cass Sunstein, Infotopia: how many minds produce knowledge. Published by Oxford University Press, Oxford, UK.
} 
topic, both because our age of information and innovation has been richly theorised as an age of risk, and because the rapid growth of the risk specialism across the public sector has created structures whose potential to serve as crucibles for innovation remains under-appreciated. Perhaps most intriguing in a discussion of this kind is how and to what degree greater information intensity within government can simultaneously serve both the prospects for effective innovation and the management of attendant risk.

\section{Elsewhere in this edition}

It is both timely and relevant to be publishing Agneta Ranerup's paper on the intertwining, the hybridity, of human and technological agency in understanding 'e-government'. Indeed the very idea that technology has agency that can usefully be theorised for its relation to human agency, is one of enduring fascination which we might root back into efforts to map that realm of mind or thought that many have called the 'noosphere', or even that realm of cultural products that Sir Karl Popper called 'World 3'. Ranerup sees the adoption of a perspective on e-government, which intertwines human and technological agency, as crucial to the striking of a new and necessary relationship between the State and its citizens. Here then, Ranerup is in effect reflecting on the need to engage citizens within what are largely conceived as technological rather than socio-technical spheres of activity, thereby enabling government to make democratic as well as efficiency gains as forms of electronic government are developed and delivered.

Finally, we present our own modest innovation in this edition of the journal. We publish a 'research note' on e-participation research written by Rony Medaglia from the Department of Innovation and Society at the University of Rome. Medaglia presents work on a literature database on eParticipation developed within the European Network of Excellence on eParticipation research, or 'Demo-net'. Medaglia offers a deconstruction of 651 published items that leads to the conclusion that this research field is in need of a more coherent and altogether stronger identity. I am keen to publish more on forms of e-participation and I am especially keen to publish more research notes of this kind, providing, in part at least, a research infrastructure for colleagues throughout the world. 